\title{
Political Islam in Pre-revolutionary Russia: Groups, Parties, Representatives in the Parliament
}

\author{
Ruslan R. Vildanov, Olga N. Budeeva, Amina G. Khasanova, Svetlana D. Galiullina, Pavel A. Minakov \\ Ufa State Petroleum Technological University \\ Ufa, Russia
}

\begin{abstract}
The article analyzes the formation, emergence, development and problems of political Islam in Russia. The authors point out that the history of the formation of political Islam in Russia dates back to the 16th century. Jadidism, which was aimed at modernizing all aspects of Muslim life and spread in the Russian Empire in the 19th century, became a key factor in the politicization of Islam. At the same time, there were also other reasons for the return to pure Islam, for example the Waisi. The revolution of 1905-1907 gave impetus to the development of Muslims as a political force. In the course of the legalization of political unions, the union of Ittifaq al-Muslimin was rose, aiming to consolidate all Muslims. The authors emphasize the peaceful nature of political Islam in pre-revolutionary Russia.
\end{abstract}

Keywords_Islam; Jadid; Ittifaq al-Muslimin; Wäisi movement; Muslim faction; State Duma

\section{INTRODUCTION}

Political Islam did not emerge in modern Russia simultaneously. In the history of Russia there were serious internal prerequisites for the politicization of Islam. Initially Islam unlike Christianity or Buddhism as a religion had a much more secular character. Islam did not pass the stage of being a religion for the poor and the outcast, and already during the lifetime of the Prophet Muhammad became the state religion. Therefore, the influence of Muslim ideology on everyday life and public policy has always been very strong. Secular and spiritual, religion and politics are the things in Islam which have always been very closely intertwined.

Moreover, Islam in Russia had its own important features. The territories inhabited by Muslims became the part of Muscovy after the conquest of the lands of the Kazan, Siberian and Astrakhan khanates. The tsarist government immediately set a course for the Christianization and assimilation of the non-Russian peoples. Orthodoxy has got the status of the official state religion, and the Russian Church - a monopoly on the missionary activity. Under Peter I, the Muslims were not only under political but also widely applied economic pressure. As a result, the cultural and economic foundations of Muslim societies have been significantly undermined. The feudal aristocracy was almost extirpated in the fifties and sixties of the XVI centuries during the popular uprisings, the so-called Cheremis Wars. Part of the aristocracy, which went to the service of the Russian tsar, gradually dissolved in the relevant layers of Russian society. The destruction of mosques, the closure of Muslim schools, the persecution of

The project has been carried out with the support of grant RFFI 17-13-

02010 "Islam in Bashkortostan: Risks of Politicization". representatives of the clergy led to a sharp reduction in the clergy. Those who managed to survive and adapt to new conditions were able to realize themselves only within the framework of the local religious community - the Ummah Therefore, Islam has become for the Muslim population the basis of their cultural and national self-identification.

Analyzing the place and role of political Islam in political process the authors of this work took into account the fact that many important aspects of the history of political Islam in prerevolutionary Russia still remain poorly studied. That is why the authors sought to carry out comprehensive scientific research.

The purpose of this study is to determine the characteristics of political Islam in pre-revolutionary Russia, estimate the specifics of its emergence and interests, the characteristics of groups, parties and trends. It is also necessary to consider the process of changing methods of fighting for their rights.

\section{MATERIALS AND METHODS}

The authors used the following methods and techniques: system analysis; comparative assessments based on categories of identity and difference, in order to identify similar, identical or different characteristics of comparative political institutions or processes; "Stages of consideration of cases" as a tool to identify patterns and obtain the necessary generalization; historical analysis: synchronous, helping to study the phenomenon in the context of historical conditions; chronological, aimed at consistent consideration of historical events; diachronic, focused on periodization and historical parallels, historical modeling in relation to political processes, technologies, institutions. Among other methods used in this study are system-functional measurement; content analysis of documents; descriptive and correlation characteristics; political and predictive tools. The empirical basis of the study include the complete collection of laws of the Russian empire; Collections of documents and materials; Materials from open sources on the Internet; Media publications. 


\section{DISCUSSION}

Since Catherine II, the authorities began to understand that it is necessary to take into account the interests of the Muslim population. Therefore, the attitude of the state to Muslim subjects improved. In the second half of the 18th century, the Muslim clergy was legalized and included in the system of public administration of the empire. Nevertheless, very serious restrictions remained in relation to the Muslim population. It is necessary to understand what exactly under these conditions, served as factors in the transformation of Islam into political force.

\section{RESULTS}

A special role in the politicization of Islam belongs to Jadidism. The term itself comes from the expression "usul and jadid," which means "new method." Initially, this meant the introduction of new methods of school education, the reform of religious schools based on Western pedagogy. One of the founders of the new movement was Ismail Bey Gasprinsky. The movement quickly went far beyond the school reform. In fact, it soon became a movement for the modernization of the Muslim religion in general. It can be noted that Jadidism became part of the general Muslim trend towards the modernization of Islam.

Conservative representatives of the clergy were negatively disposed towards Jadidism. This movement received the name of the cadimists, from the word "Kadima", which means "the original, unchanged."

Along with this movement, in the second half of the 19th century, appeared the movements aimed at the purification of Islam. Kazan merchant Bagautdin Vaisov during his trips to Central Asia became acquainted with the activities of the Sufi Order of Naqshbandiya. Bagautdin Vaisov was attracted by this order with the fact that the main authority there was not the official clergy, but mentors. He considered himself a descendant of the Prophet Mohammed, and on the maternal line he built his ancestry to the Bulgarian Khans [6]. In 1862, Vaisov opened a "state prayer house" in Kazan. There he began to gather his followers and teach the "true faith." According to Vaisov, Islamic dogma is distorted and it must be "cleared" of layers, which was close to the ideas of Salafis [7]. This caused discontent with the official Muslim clergy. In 1884, the police defeated the prayer house of Vaisov. The leader of the movement, Bagautdin Vaisov, was arrested and placed in a Kazan psychiatric hospital, where he died in 1893. The son of Bagautdin Vaisov, Gaynan Vaisov, after returning from exile in 1906, restored the prayer house.

Religiously and dogmatically, the Wäisis spoke under the slogan of returning to "Pure Islam." According to Bagautdin Vaisov, a true Muslim should live according to the Qur'an and at the same time should not abandon "the custom of the Prophet Muhammad and change him." The main enemies of "true Islam" in his opinion were the Tatar clergy associated with the Russian authorities, and the local administration. The greatest hostility, like the Wahhabis, Vaisov and followers felt to Muslims, who"distorted" Islam. At the same time, prerevolutionary researchers noted in his teachings the absence of religious intolerance towards non-Muslims (in particular, towards Christians) [3].

The basis of the Wäisis were peasants, small traders, artisans who were trying to defend the special status of Islam, and to clean it from the later layers (in their understanding of the term). The originality of the movement consists in heterogeneity, connection with various not only local, but also other Islamic and non-Islamic movements, close connection of religious and national aspects of the teachings, and desire to achieve their goals exclusively by peaceful means.

The Wäisi movement was a special phenomenon in political Islam. This is confirmed by the fact that even after arrests and the defeat of the organization, the supporters of Vaisov continued to operate in the underground. During the Civil War, the Wäisis would support the Bolsheviks.

An important milestone in the development of political Islam as a real political force was the revolution of 1905-1907. During the revolution, protesters managed to force the authorities to go for reforms. In particular, the Manifest of October 17, 1905 became an important concession to Nicholas II. It guaranteed the freedom of conscience, the right of citizens to organize unions.

Liberal Muslim circles led by Ismail Bey Gasprinsky decided to organize in the groups to protect their interests. On August 15, 1905, the All-Russian Congress of Muslims was held in Nizhny Novgorod. It was attended by delegates from the Crimea, the North Caucasus, Transcaucasia, Kazan, the Urals, Turkestan and Siberia. The congress was dedicated to the issue of an organizational form of the Muslim movement. During the Congress, moderate views prevailed, and it was decided to create a Muslim union instead of a political party. The union received the name Ittifak al-Muslimin, which in Arabic means the consent of the Muslims [5].

In political views, the Ittifakians were close to the Cadets. The Ittifak program, adopted at the III All-Russian Muslim Congress in August 1906, included the following provisions: the establishment of a constitutional monarchy in the country, the preservation of private property, and the cultural and national self-determination of the Turkic peoples within Russia.

As the main task of the Union of Muslims, its creators saw the union of all Muslims of the Russian Empire in one movement. An important issue was also the legal inequality of the Muslim population. That is why the union set as one of its priorities the abolition of laws and administrative practices that discriminated Russian Muslims.

One of the positive results of the 1905 revolution was also the emergence of Russian parliamentarism. This meant a transition from absolute monarchy to parliamentary. Of course, the parliament restricted the rights of the king only formally, but its work made a significant contribution to the history of Russian parliamentarism. In a relatively short time, it was carried out an active legislative work. The new parliament consisted of 2 chambers: the upper one of the already existing State Council, and the lower one - the State Duma. The upper house was partly appointed by the king, partly elected by the Zemstvos, Academy of Sciences. The lower one was chosen 
by the population according to a complex multistage system [1].

The State Duma became the first place where the Russian Muslims for the first time were able to speak out about their problems. And there were a lot of them. After all, the royal Manifest of October 17, 1905 guaranteed equality only on paper. The problems of national school, violation of freedom of religion, and the land question remained unsolved.

Among the participants in the Duma were 22 Muslim deputies, which were representing the Turkic peoples of Russia (Tatars, Bashkirs, Azerbaijanis, Kazakhs). Already in the State Duma of the first convocation emerged a Muslim faction of 22 people. Its first meeting was held on June 21, 1906 [8]. And Muslim faction was the only faction formed on a confessional basis. All problems which the Muslim population of the Russian Empire were facing were discussed by the Muslim faction. The Duma was a platform for the Muslim public, the only way to change the existing order. When the first Duma was dissolved, three months later, the electoral legislation was amended to reduce the number of non-Russian nationalities.

An important role in conducting a successful election campaign among Russian Muslims was played by the union "Ittifak el muslimin". At the second Muslim congress (January 1906), the electoral tactics of "Ittifaka" was to build the union with the Cadet party. The entire leadership of the faction of Muslim deputies was represented in the Duma "Union of Muslims". The political influence of the Ittifak leaders on the Muslim faction was very strong. We can say that the Muslim faction was formed as the parliamentary faction "Ittifak el muslimin".

As part of the State Duma of the 2nd convocation, the Muslim faction already numbered 36 people. But unlike the State Duma of the 1st convocation, the elections to the 2nd Duma were not boycotted by the left parties. Therefore, the composition of the deputies of the 2 Duma was much more radical and oppositional and this fact got the reflection the Muslim movement. In March 1907, an independent "Muslim labor group" of 6 deputies was singled out from the Muslim faction. [2]. This mean, that already by 1906 , emerged two movements: the liberal and socialist. Muslim labors criticized the Muslim faction, arguing that it protects only the interests of the elite of the Muslim population. They also criticized their former colleagues for being too, in their opinion, liberal and for cooperation with the Cadets and Octobrists. The agrarian question has become the main stumbling block. Labors reflected the sentiments of the national village, and were in favor of confiscating landlords' land.

In June 3, 1907 simultaneously with the dissolution of the Second State Duma was also changed the electoral legislation. The new electoral law significantly limited the electoral rights of peasants and workers, putting in a privileged position landowners. It also provided the Minister of the Interior the right to change the boundaries of electoral districts and to divide electoral assemblies into independent branches at all stages of elections, for example, on a confessional basis. Electoral law of June 3, 1907. greatly reduced the representation of the suburbs (the overall reduction in the number of the Duma was carried out mainly at their expense). So, the representation of the Caucasus was reduced from 29 to 10, the representation of Siberia and the Far East - from 22 to 15. The territories of Central Asia, Kazakhstan were completely deprived of representation (they had previously 24 deputies) [4].

This tendency was affected the number of deputies from the Muslim population. As the authorities did not allow the Muslim Union to develop into a full-fledged party, against the background of the fall of revolutionary sentiments in 1907, Ittifak al-Muslimin ceased his activities. In the Duma of the III convocation, its number was reduced to 9 deputies, in the IV Duma it numbered only 6 people. Nevertheless, even in such a truncated composition, the faction played a large role in the organization of the Muslim population in the Russian Empire. In February 1916, at the Muslim faction was organized a bureau which was coordinating the activities of the Muslim movement in the Russian Empire. In general, it can be noted that it was in the Muslim faction and its bureau where many political leaders, A.N. Bukeikhanov, A.A. Topchibayev, H.G. Khas-Mamedov, F.I. Khan-Khoysky, A.-V. Validov got an experience of political activity.

\section{CONCLUSION}

The politicization of Islam in Russia coincided with the general trends in the development of Islamic social thought in the Muslim world. Against the background of lagging behind the West, politicians and ideologists came up with ideas of modernization, reforming all aspects of life. These ideas were embodied in Jadidism in Russia. It was Jadidism that allowed Ittifaq al-Muslimin to appear. Unfortunately, this political association did not manage to turn into a legal political party that could coordinate the defense of the interests of the entire Muslim population of the Russian Empire. Because of the fears of the Russian authorities that the emergence of such a force would lead to the strengthening of Pan-Turkism, PanIslamism, the influence of the Ottoman Empire in Russia, these plans were not realized.

Just as in the rest of the Muslim world, in addition to the tendencies towards reform and modernization, there were groups advocating a return to "pure Islam" without distortion. That was clearly manifested by Vaisov and his supporters.

The main thing is that the political Islam in prerevolutionary Russia had exclusively peaceful, non-violent nature. Even the Wäisis with their rather radical ideas, did not express negative ideas about Christians, the authorities. All movements in political Islam advocated peaceful solutions of the problems, the search for a compromise. 


\section{REFERENCES}

[1] R.R. Vildanov, "The specifics of the political system of the Russian empire in the early twentieth century," Eurasian Law Journal, 3 (70), pp 201-203,2014.

[2] D.F. Gallyamov, "Muslim Labor Group" as one of the vectors of the social and political life of the Turkic Muslims of the Ural-Volga region of the early twentieth century," Kazan Pedagogical Journal, 7, p. 89, 2013.

[3] Yu.N. Guseva, "Wäisi movement in the Volga-Ural region in the context of the Islamic "reformation" of the late XIX - the first third of the XX Century," Bulletin of the RSUH. Series: History. Philology. Culturology. Orientalism, 10 (111), pp. 43-57, 2013.

[4] V.A. Demin, State Duma of Russia: the mechanism of functioning. Moscow: Russian political encyclopedia, 1996.

[5] D.M. Usmanova, "Ittifak al-Muslimin," in The Great Russian Encyclopedia. Moscow, 2008.

[6] M. Kemper and D.M. Usmanova, "Wäisi movement in the mirror of his own petitions and poems," Gasyrlar Avazy - Echo of the Centuries, 3-4, pp. 274-277, 2001.

[7] D.M. Usmanova, Muslim "sectarianism" in the Russian Empire: "Vaisov God's Regiment of Muslim Old Believers", 1862-1916. Kazan, 2009.

[8] L.A. Yamaeva, Muslim deputies of the State Duma of Russia, 19061917. Ufa: Kitap, 1998. 